\title{
THE VARIANT APPROACH TO THE OPTIMIZATION OF THE POSTAL TRANSPORTATION NETWORK IN THE CONDITIONS OF THE SLOVAK REPUBLIC
}

\author{
Radovan Madleňák1, Lucia Madleňáková², Jozef Štefunko ${ }^{3}$ \\ ${ }^{1}$ University of Zilina, Zilina, Slovakia, \\ ++412/41/5133124,radovan.madlenak@fpedas.uniza.sk \\ ${ }^{2}$ University of Zilina, Zilina, Slovakia, \\ ++412/41/5133125, lucia.madlenakova@fpedas.uniza.sk \\ ${ }^{3}$ University of Zilina, Zilina, Slovakia, \\ ++412/41/5133144, jozef.stefunko@fpedas.uniza.sk
}

\begin{abstract}
The optimizing process of the postal transportation network can be based on several variables and on different infrastructures. The most commonly used variables for optimization are time and distance. This article is focused on the comparison of the results of the optimization process based on the time and distance variables in the conditions of the Slovak national postal operator.

The different types of the underlying infrastructures (roads or railways) could be used for optimization based on the territory conditions. For the optimization, there has been used the p-median method, that describes the problem of locating $\mathrm{P}$ "facilities" relative to a set of "customers" in such a way that the sum of the shortest demand weighted distance between "customers" and "facilities" is minimized.

In the conclusion, the article authors will formulate the rule for selection of the best optimization variables for the postal transportation network optimization.
\end{abstract}

Keywords: optimization, postal transportation network, distance, time, infrastructure, p-median

\section{Introduction}

An appropriate location decision is the key to optimally solve a variety of public and private problems, since poor location can result in various negative scenarios. We can consider such decisions as critical, or strategic. In the private sector it can lead to increasing costs, loss of competitive advantage and market share. The location theory provides many different approaches, procedures and solutions to support the decisions of locating facilities, either building new ones or relocating the existing ones. The choice of solution depends exclusively on the nature of the problem, known inputs, decision variables and the outputs we want to achieve. In location models, demands and candidate locations are discretized to simplify the solution. These models also assume that there is an underlying network for the problem, consisting of certain infrastructures, such as transport or other logistic connections. (Droździel, Komsta and Krzywonos, 2008) The distance between demand nodes and facility locations is not necessarily the physical distance. It could be also the travel time, travel costs, etc. (Ahuja, Magnanti, and Orlin, 1993)

The design of a suitable system of postal technology is the most important issue for providing the elementary functions of the postal enterprise. A correct technology decision depends on the chosen postal infrastructure model and specific technological methods and processes. (Droździel, 2008) The designed model takes into consideration the demands of the outside postal environment and the requirements of the high level automation equipment in the conditions of postal enterprises.

\subsection{Analysis of the problem}

On the basis of the essential postal technology terms, it is important to analyse the main areas which influence the whole technological process of the postal items processing. The analysis determines the critical part of the whole optimization process - the choice of a suitable construction variant of the postal transportation network (Madleňák, 2002).

The most suitable construction variant of the postal transportation network is selected from the experiences of the postal enterprises in two European countries, which are comparable to Slovakia in the geomorphologic character and demographical structure (Čorejová, 1995). The chosen countries are Swiss 
and Denmark. The construction variant of the transportation network that seems to be the optimum for these countries conditions is a hierarchical three-level model of the postal transportation network (Figure 1).

High level (HL)

Middle level (ML)

Low level (LL)

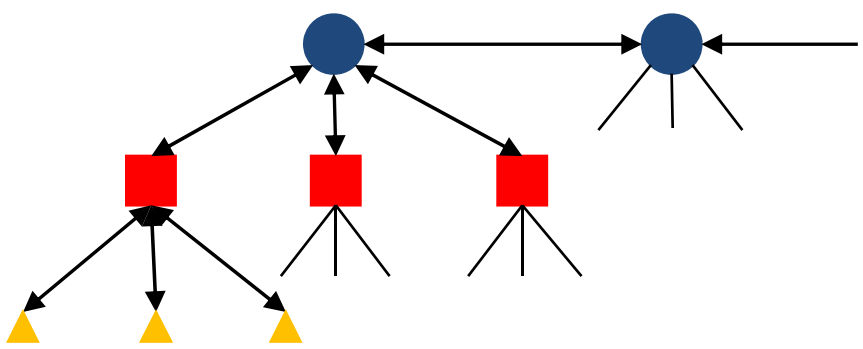

Figure 1. Hierarchical three-level model of postal transportation network (Madleňák, 2003)

After choosing the construction model of the transportation network, it is necessary to determine the number and the placement of each node at all levels of the postal network. For the reasons to reach the real results, the postal optimization process is realized in the conditions of the Slovak postal enterprise - Slovak Post.

The existence of the transportation network of the Slovak Post determined the variant-oriented optimization process. Therefore, a two-phase optimization method has to be created, which, at first, reevaluates the existence of the middle level nodes and, then, suggests the number and the placement of the highest level nodes of the postal transportation network (Madleňák and Madleňáková, 2006).

\section{First phase of optimization}

In the first optimization, the phase mathematic-statistics methods could be used to reduce the number of the middle level nodes or to re-evaluate the position of the zone centres. As an optimal for this phase optimization there could be used the methods of multi-criteria analysis (Madleňák and Zeman, 2009):

- rating method;

- method of scaling factors;

- method of standardized variable;

This methods works with the set of demographical and geographical attributes, which represents the characteristics of the particular middle-level regions:

- number of villages (or cities) in the middle-level region;

- number of villages (or cities) with postal offices in the middle-level region;

- number of citizens in the middle-level region;

- total area of the middle-level region;

- total distance between the middle-level region centre and each villages (or cities) in the middlelevel region;

- total distance between the middle-level region centre and each village (or city) with a postal office in the middle-level region;

The part-optimized model of the transportation network is depicted in the form of a graph, which served as the basis for the second phase of the optimization (Fig. 2).

The graph $\mathrm{G}=(\mathrm{V}, \mathrm{E})$ is intuitively defined as a pair consisting of a set of nodes and a set of edges. The graph $G$ is a set of vertex (nodes) $V$ connected by edges (links) E.

The node $\mathrm{V}$ is a terminal point or an intersection point of the graph. It is the abstraction of a location such as a city, an administrative division, a road intersection or a transport terminal (stations, terminuses, harbours and airports).

The edge $E$ is a link between two nodes. The link ( $i, j$ ) is of initial extremity $i$ and of terminal extremity $\mathrm{j}$. The link is the abstraction of a transport infrastructure supporting the movements between the nodes (Drezner, 1995).

For modelling the postal transportation network nodes we used a weighted graph where the weight assigned to each node (a node is location of the postal item processing centre) represent the importance of the node in the graph and the weight assigned to the edge could be represented in two ways:

- metric distance (in $\mathrm{km}$ ),

- travel time (in minutes). 


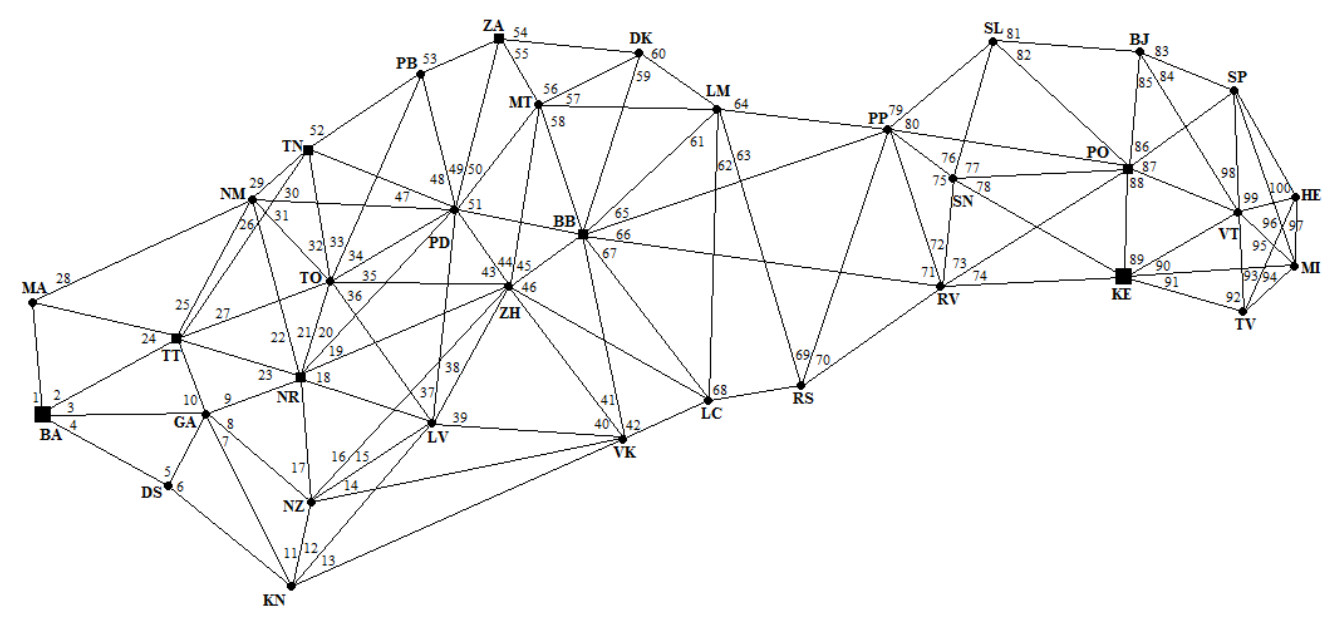

Figure 2. Model of postal transportation network - graph after first phase optimization (Madleňák, 2003)

\section{Second phase of optimization}

In the second part of the optimization it is important to choose a suitable optimization method to find the optimum number and placement of the highest level nodes of the postal transportation network. One class of location problems deals with covering of demands by at least one facility. We can either find the minimum number of facilities needed to cover all the demand nodes at least once (set covering model) or maximize the number of the covered demands by locating a fixed number of facilities (maximum covering model). Another class is centre problems. Solution to these problems is to find location of a certain number of facilities, so that the maximum coverage distance is as small as possible (p-centre problem). To consider the benefits obtained within the coverage distance or beyond the coverage distance, there is a class of median problems. Since we consider the p-median problem as the most appropriate for our work, we will describe it further (Madleňák, Madleňáková, Pavličko 2014).

\subsection{P-median problem}

The p-median model locates $\mathrm{p}$ facilities to minimize the demand-weighted average distance resulting in minimizing of total costs. The cost of serving demands at a specific node is given by the demand at the node and the distance between the demand node and the nearest facility to that node. This problem may be formulated as follows (Hakimi, 1964):

\section{Inputs}

$h_{j}$ - demand at node $i$

$d_{i j}$ - distance between demand node $i$ and candidate site $j$

$P$ - number of facilities to locate

\section{Decision Variables}

$X_{j}=1 \quad$ if we locate at candidate site $j$

$$
\begin{array}{ll}
X_{j}=0 & \text { if not } \\
Y_{i j}=0 & \text { if not }
\end{array}
$$

$Y_{i j}=1 \quad$ if demands at node $i$ are served by a facility at node $j$

\section{Minimize}

$\sum_{i=1}^{n} \sum_{j=1}^{n} h_{i} d_{i j} Y_{i j}$

\section{Subject to:}

$\sum_{j=1}^{n} Y_{i j}=1 \quad \forall i$

$\sum_{j=1}^{n} X_{j}=P$ 
The objective function (1) minimizes the total demand-weighted distance between each demand node and the nearest facility. Constraint (2) requires each demand node $i$ to be assigned to exactly one facility $j$. Constraint (3) states where exactly the $P$ facilities are to be located. (Daskin 1995)

While the P-median problem can be solved easily on a tree network, in complex real networks the solution is difficult and time-consuming to find. Thus, a number of heuristic algorithms have been proposed. These heuristics fall into two classes: construction algorithms and improvement algorithms. The basic construction algorithm is a myopic algorithm (Figure 3). This algorithm tries to find the initial solution based on the consecutive selection from optimal locations for 1-median problem.

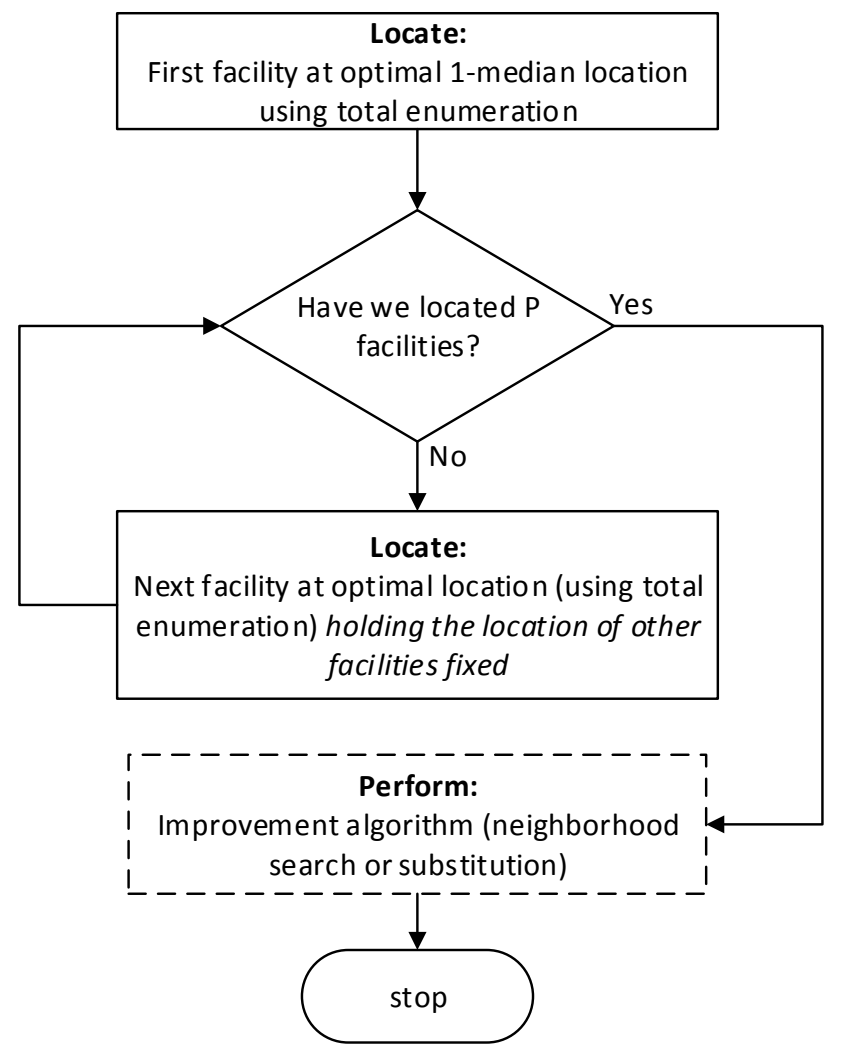

Figure 3. Myopic algorithm with improvement heuristic shown after all facilities are located (Daskin 1995)

Solution is not always optimal for the p-median problems (except 1-median), therefore this algorithm is used only as first step for other algorithms. The aim of the improvement algorithms is to find an optimal or a sub-optimal solution for the facility location. The substitution algorithm minimizes the average weighted distance by replacing one of the considered nodes by another node. The improvement of the objective function is observed for each replacement. In case of the improved solution, the nodes are replaced permanently and we continue until all the nodes are considered for a possible location. Anther improvement algorithm is a neighbourhood search algorithm (Mesa, Boffey, 1995). This algorithm can also begin with any set of $\mathrm{P}$ facilities. For each facility, the algorithm identifies the set of demand nodes that constitute the neighbourhood around the facility. Within each neighbourhood, the optimal 1-median is found by the myopic algorithm. If any sites are changed, the algorithm relocates the demands to the nearest facility and creates new neighbourhoods. If any of the neighbourhoods changes, the algorithm again finds the 1-median within each neighbourhood, and so on. By integrating the myopic algorithm into one of the improvement algorithms, we can find an optimal solution for minimizing the total demand-weighted distance between the demand nodes and the facilities.

\section{Results}

Variant - time represents the solution for optimizing the location of the main centers in the postal transportation network when we use the travel time between the neighboring nodes as an edge weight. This 
attribute is specified as the time taken to travel the distance between the nodes of the postal transportation network in minutes. When we process the optimization procedure to allocate the main nodes using the pmedian allocation model we come to the following result.

When we want to find only a single main center, the location of this center is placed in the node Žiar and Hronom. The average time needed to serve all nodes from the main node is 139 minutes and the maximum time for covering the farthest node from the main node is 296 minutes.

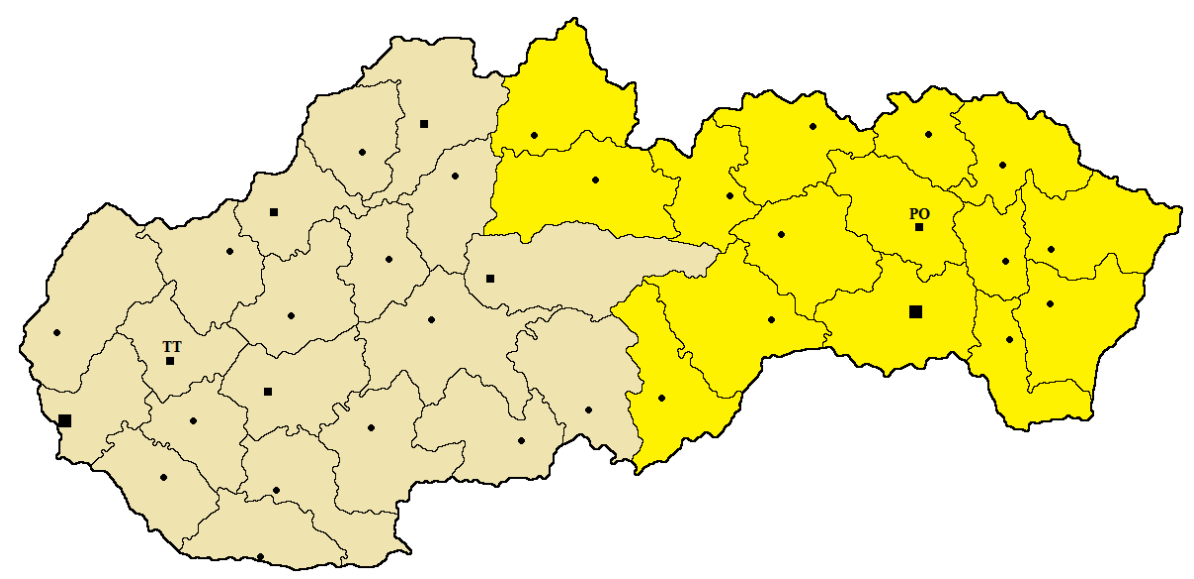

Figure 4. Allocation of two centers in Variant - time model

If we try to find two main centres in the network graph, based on the optimization, these two nodes will be allocated at Trnava and Prešov (Figure 4). Compared with the previous solution we can see the reduction of the average time needed to serve all nodes from the main nodes from 139 minutes to 68 minutes and the maximum time for covering the farthest node from the main nodes to 181 minutes.

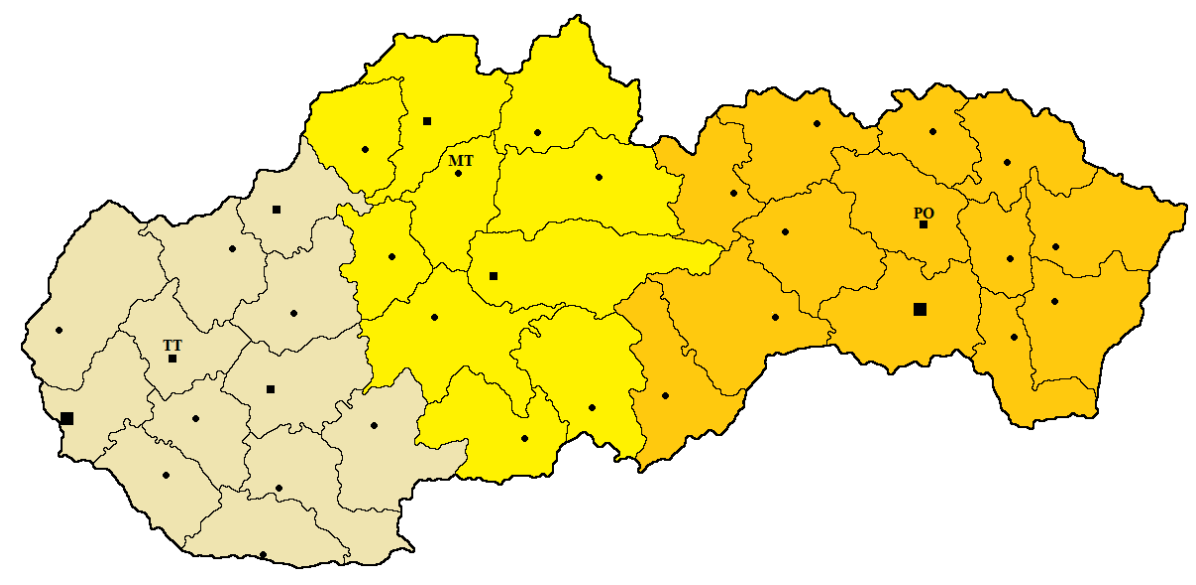

Figure 5. Allocation of three centers in Variant - time model

When we search for three main nodes in the network graph, where the edges are weighted by the travel time, these main nodes will be allocated at the nodes of Trnava, Martin and Prešov (Figure 5). The average time needed to serve all the nodes from the main nodes is reduced to 51 minutes and the farthest node is situated 157 minutes from the head nodes.

When trying to find the four main centres in the travel time criteria edge weighted network graph, the main centres are allocated at the of nodes Bratislava, Nitra, Martin and Prešov (Figure 6). When the postal transportation network will be served from these designated main nodes, the average time needed to serve all the nodes from the main nodes will be 44 minutes and the farthest node will be the same as in the previous variant ( 3 main centres) 157 minutes away from the main nodes. 


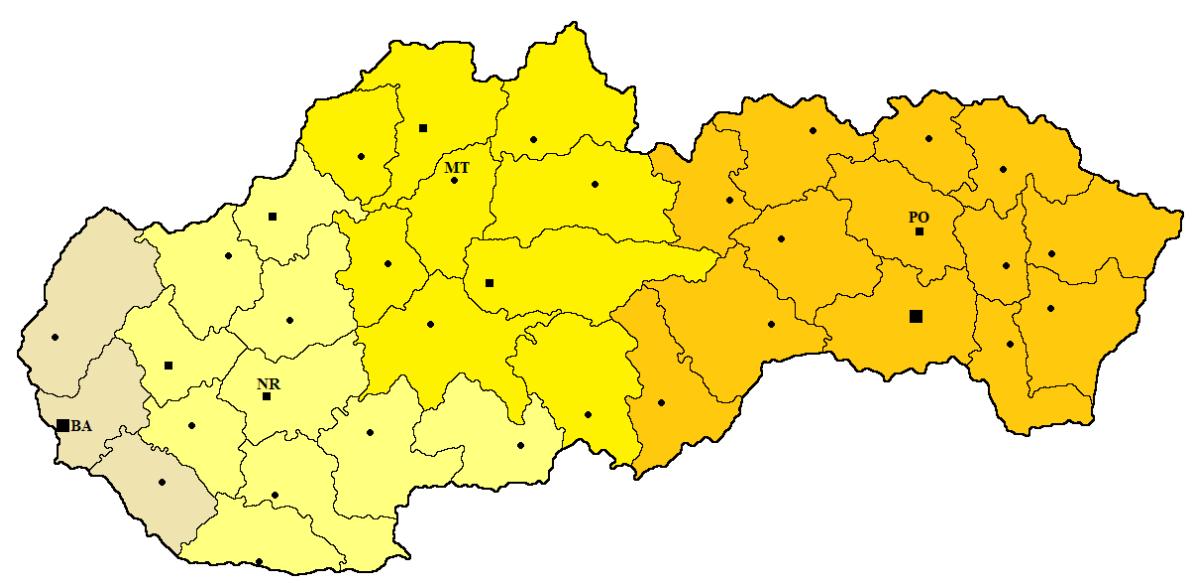

Figure 6. Allocation of four centers in Variant - time model

In the Variant - distance we are trying to optimize the location of the main nodes in the postal transportation network based on the assumption that the weighting assigned to the edges of the network graph is specified as the shortest distance between the neighbouring network nodes expressed in kilometres.

If we look for only one main centre in the network graph, then the result of applying the p-median allocation model is the same as in the variant - time. The main node will be located at node Žiar nad Hronom (Figure 7). The average distance between the main node and all nodes of the network was estimated as 151 $\mathrm{km}$. The maximum distance between the main node and the covered nodes network was $314 \mathrm{~km}$.

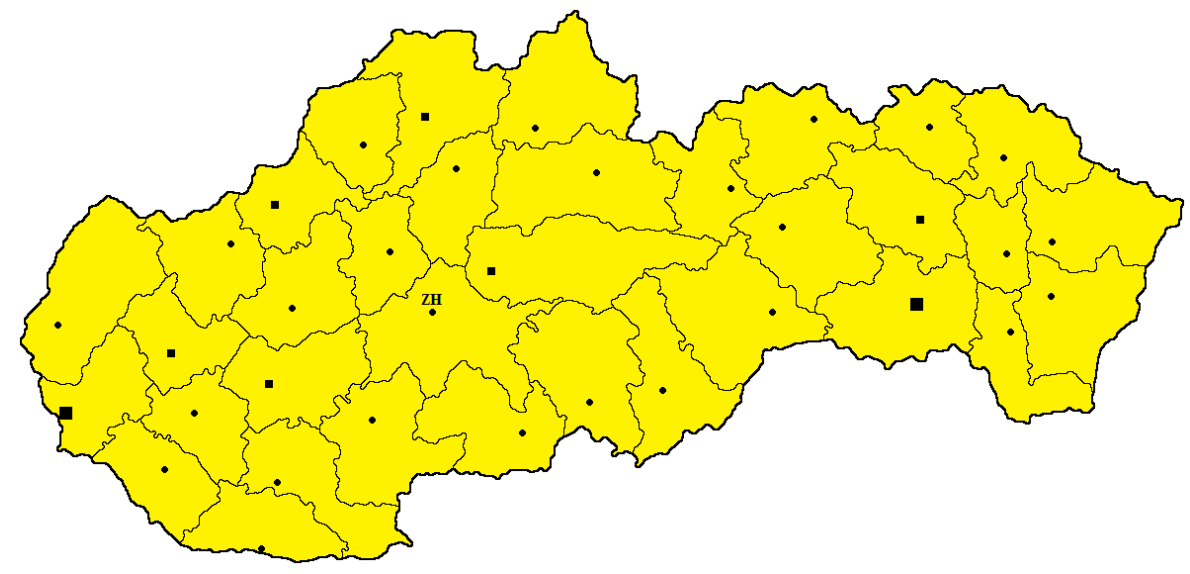

Figure 7. Allocation of one center in Variant - distance model

In the variant when we search for two main nodes in the network graph, the main centres are allocated at Nitra and Prešov (Figure 8). The average distance network of the nodes from the central nodes was $79 \mathrm{~km}$ and the maximum distance between the main node and the covered nodes network was $171 \mathrm{~km}$.

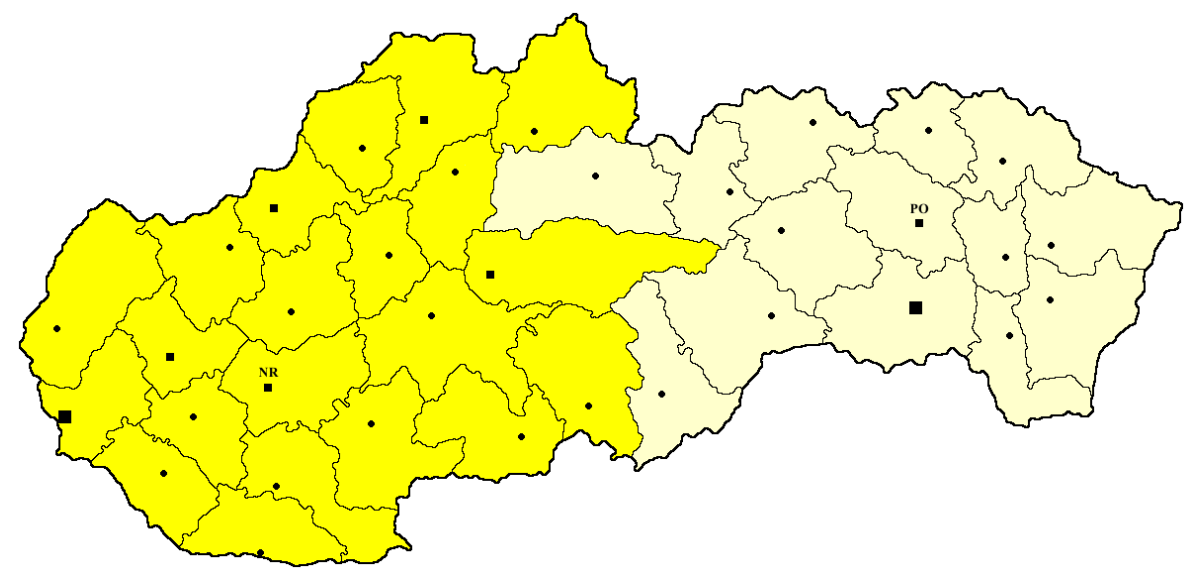

Figure 8. Allocation of two centers in Variant - distance model 
The biggest difference between the variants of distance and time is just in the case when we search for three main centres in the postal transportation network. In the variant - time, the main centres were allocated at Bratislava, Prešov and Prievidza (Figure 9). The average distance between the central nodes and the covered network nodes was $53 \mathrm{~km}$ and the maximum distance between the main node and covered nodes network was $148 \mathrm{~km}$.

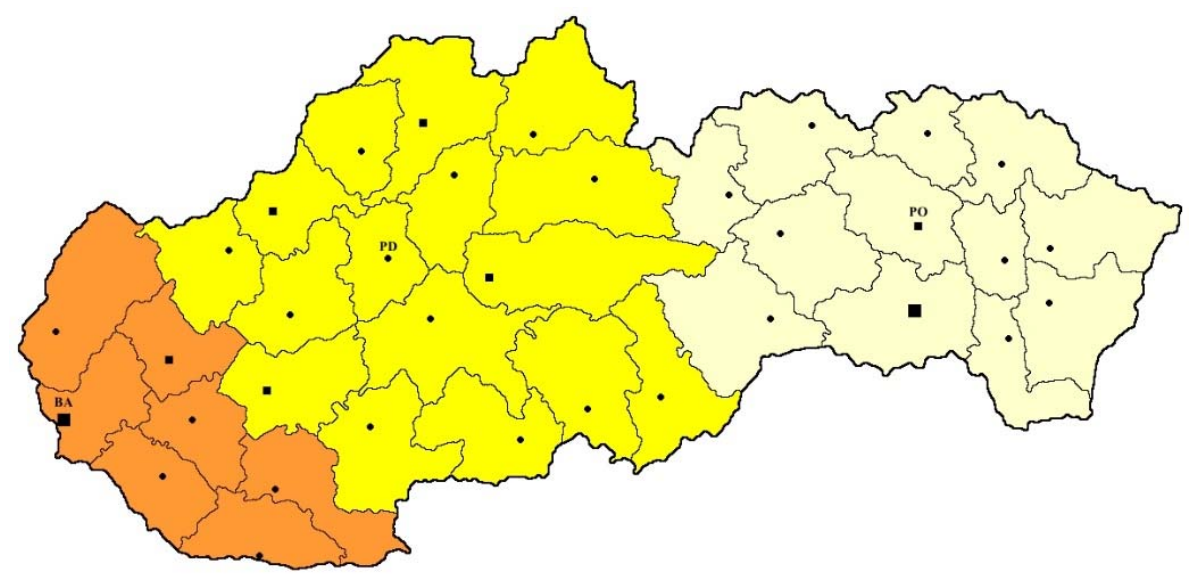

Figure 9. Allocation of three centers in Variant - distance model

The results of four main nodes allocation in the network graph were the same in both variants of distance and time. The main centres were allocated to Bratislava, Nitra, Martin and Prešov (Figure 10). The attribute average distance between the main nodes in the network and the covered nodes was $43 \mathrm{~km}$ while the farthest node was $150 \mathrm{~km}$ away from the main nodes.

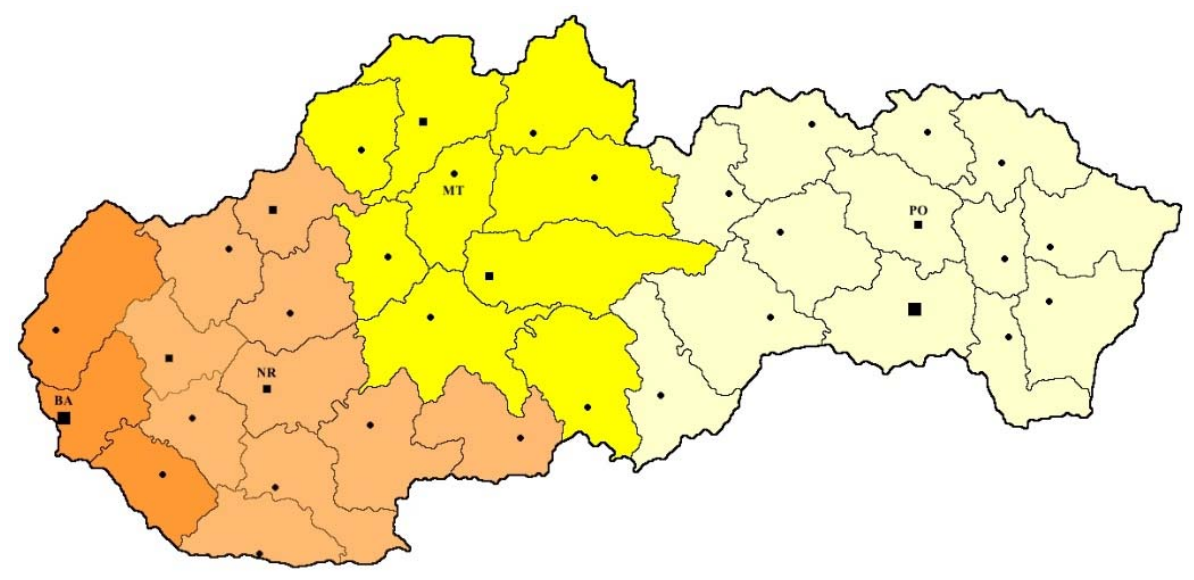

Figure 10. Allocation of four centers in Variant - distance model

\section{Conclusions}

The results of the application p-median allocation model on the underlying network graph (where the edges were variantly weighted by the travel time and the metric distance) bring some interesting findings.

In the case of allocating a single main centre in the postal transportation network, it is not important if we take into consideration the travel time or the distance for weighting the graph edges. In both cases we find at the location of the main centre to node Žiar nad Hronom.

When we want to allocate two main centres in the variantly constructed postal transportation network we will reach the different results. The location of the main centre at the to node Nitra (the edges weighted by the metric distance) is due to the advantageous geographic location of the node Nitra in its attraction area and location of the main centre at the node Trnava (the edges weighted by the travel time) is due to the most comfortable position of the node Trnava regards the transport infrastructure (mainly the 
highway) in the attraction area. Location of the main centre at the node Prešov is given by its position in the graph (Prešov is located in the geographical centre of the region) and also by its good access to the highway.

In the case of the three main centres allocation we can see a clear impact of a better infrastructure on the location of the main centres. In the time variant, the edges weighted by the travel time between the neighbouring nodes of graph resulting in enlarging the attraction area in places where exist a higher quality transport infrastructure (highways existence), and for the distance variant is visible centrist location of the main node Prievidza within its attraction area.

By searching four or more main centres in the network graph we reach the same result (allocation of the centres) for both variants. A very interesting finding of this research is that the maximal covering distance in the variants of four centres is equal or higher than in the variants of three centres. It means that allocation of three high level centres in the conditions of the Slovak republic is optimal.

Table 1. Summary of time/distance optimization variants

\begin{tabular}{|c|c|c|c|}
\hline Parameter & Model & Time variant & Distance variant \\
\hline Average time/distance & \multirow{3}{*}{1 center allocation } & 138,56 minutes & $151,45 \mathrm{~km}$ \\
\hline Maximal time/distance & & 296 minutes & $314 \mathrm{~km}$ \\
\hline Allocated center & & Žiar nad Hronom & Žiar nad Hronom \\
\hline Average time/distance & \multirow{3}{*}{2 centers allocation } & 67,91 minutes & $79,36 \mathrm{~km}$ \\
\hline Maximal time/distance & & 181 minutes & $171 \mathrm{~km}$ \\
\hline Allocated centers & & $\begin{array}{l}\text { Trnava } \\
\text { Prešov }\end{array}$ & $\begin{array}{l}\text { Nitra } \\
\text { Prešov }\end{array}$ \\
\hline Average time/distance & \multirow[b]{3}{*}{3 centers allocation } & 51,39 minutes & $53,12 \mathrm{~km}$ \\
\hline Maximal time/distance & & 157 minutes & $148 \mathrm{~km}$ \\
\hline Allocated centers & & $\begin{array}{l}\text { Trnava } \\
\text { Martin } \\
\text { Prešov }\end{array}$ & $\begin{array}{l}\text { Bratislava } \\
\text { Prievidza } \\
\text { Prešov }\end{array}$ \\
\hline Average time/distance & \multirow[b]{3}{*}{4 centers allocation } & 43,88 minutes & $43,16 \mathrm{~km}$ \\
\hline Maximal time/distance & & 157 minutes & $150 \mathrm{~km}$ \\
\hline Allocated centers & & $\begin{array}{l}\text { Bratislava } \\
\text { Nitra } \\
\text { Martin } \\
\text { Prešov }\end{array}$ & $\begin{array}{l}\text { Bratislava } \\
\text { Nitra } \\
\text { Martin } \\
\text { Prešov }\end{array}$ \\
\hline
\end{tabular}

In conclusion, we can state that the postal transport network (represented by the network graph), where the edges are weighted by the travel time or the metric distance between the neighbouring nodes, brings different results if we want to allocate more than one and less than four main centres. The difference between the weighing of the edges by distance or time in the network graph to allocate large amounts (more than three) of the main centres in the conditions of the territory similar to the Slovak Republic is disadvantageous.

Generalization of the knowledge gained from the research presented in this article can be concluded as follows: the choice of the optimization criteria of postal transportation network is dependent on the size and character of the territory (where takes place optimization) and optimization parameters (mainly covering distance of the attraction area).

\section{Acknowledgements}

VEGA 1/0721/15 - Research on the impact of postal services and telecommunication convergence on regulatory approaches in the postal sector (Výskum vplyvu konvergencie poštových služieb a služieb elektronických komunikácií na regulačné prístupy v poštovom sektore)

VEGA 1/0515/15 - Endogenous factors of the IPR intensive Industries in the regional enterprise environment in the Slovak Republic (Endogénne faktory v odvetviach náročných na ochranu duševného vlastníctva v regionálnom podnikatel'skom prostredí v SR)

\section{References}

1. Ahuja, R.K., Magnanti, T.L., Orlin, J.B. (1993) Network Flows: Theory, Algorithms, and Applications. Prentice Hall, New Jersey, 1993. ISBN 978-0-136-17549-0. 
2. Čorejová, T., Achimský, K., Fitzová, M., Kajánek, B. (1995) Postal networks design I. Publishing house of VŠDS, Žilina, 1995. ISBN 80-7100-238-0.

3. Daskin, M.S. (1995) Network and Discrete Location: Models, Algorithms and Applications. John Wiley and Sons, Inc., New York, 1995. ISBN 0-471-01897-X.

4. Drezner, Z. (1995) Facility Location: A Survey of Applications and Methods. Springer-Verlag, Berlin, 1995. ISBN 978-0-387-94545-3.

5. Droździel, P. (2008) The influence of the vehicle work organization conditions on the engine start-up parameters In : Eksploatacja i Niezawodność, nr 1 (37), 2008, s. 72-74

6. Droździel, P., Komsta, H., Krzywonos, L. (2013) Repair cost and the intensity of vehicle use In : Transport Problems, vol. 8, issue 3, 2013, str. 131-138

7. Hakimi, S.L. (1964) Optimum Location of Switching Centers and the Absolute Centers and Medians of a Graph. In: Operations Research vol. 12, 1964, str. $450-459$.

8. Madleňák, R. (2002) To problem of postal transportation networks construction. In: proceedings Studies of Faculty of Operation and Economics of Transport and Communications, Žilinská univerzita v Žiline, Žilina, 2002, str. 105 - 110. ISBN 80-8070-021-4.

9. Madleňák, R. (2003) Optimal model of postal item's processing technology, disertation thesis, Katedra spojov, FPEDAS, ŽU v Žiline; 2003

10. Madleňák, R. (2003) Proposal of postal transportation network model; In: Conference proceedings PERNER'S CONTACT 2003, Univerzita Pardubice, Pardubice, 2003, str. 6-11, ISBN 80-7194-524-2

11. Madleňák, R., Madleňáková, L. (2006) Postal network optimization approaches. In: Conference proceedings "New opportunities for transport and communications", Pardubice: University of Pardubice, Jan Perner Transport Faculty, 2006. ISBN 80-7194-880-2.

12. Madleňák R., Madleňáková L., Pavličko M. (2014) Postal Transportation Network: Design and Construction. Žilina. Žilinská Univerzita, 2014, p. 236. $\square$ ISBN 978-80-554-0903-0

13. Madleňák, R., Zeman, D. (2009) Construction of postal transportation network in conditions of Slovak republic. In: Postpoint 2009: conference proceedings. - Žilina: Žilinská univerzita, 2009. - ISBN 97880-554-0085-3.

14. Mesa, J.A., Boffey, T.B. (1995) A Review of Extensive Facility Location in Networks. In: European Journal of Operational Research, 1995, str. 592 - 603. 